\title{
The Influence Of Giving Incentives And The Application Of Work Discipline To The Working Satisfaction Of Permanent Employees In The Office Of Pejarakan Sub District, Probolinggo
}

\author{
Hermanto Hermanto \\ Universitas Panca Marga Probolinggo
}

A R T I C L E I N F O

\section{Article history:}

Received 23

Desember 2017

Received in revised form

10 Januari 2018

Accepted 20 Januari 2018

Available online 22

Februari 2018

Kata Kunci:

Insentif dan

Kepuasan Kerja,

Disiplin Kerja.

Keywords:

Incentive and Job

Satisfaction, Work-

Discipline.
A B S T R A K

Penelitian ini bertujuan untuk mengetahui dan menganalisa insentif dan disiplin kerja pengaruhnya terhadap kepuasan kerja karyawan di Kecamatan Pajarakan, Probolinggo. Jenis penelitian explanatory adalah untuk mengetahui pengaruh atau hubungan kausal antar variabel, Populasi seluruh karyawan di kecamatan Pajarakan dengan teknik purposive sampling dengan menggunakan kriteria inklusi adalah karyawan tetap dan mereka yang bersedia menjadi responden sebanyak 20 orang. orang, analisis regresi linier berganda dengan uji $F$ dan uji-t sebagai uji hipotesis. Hasil penelitian menggambarkan insentif dan disiplin kerja berpengaruh secara simultan terhadap kepuasan kerja, dan variabel insentif parsial berpengaruh secara signifikan dan dominan terhadap variabel kepuasan kerja sedangkan variabel disiplin kerja sebagian berpengaruh positif namun tidak signifikan terhadap variabel kepuasan kerja. Menunjukkan penerapan disiplin kerja membutuhkan pemahaman dan kesadaran yang memadai. Indikator kinerja memiliki korelasi terendah terhadap insentif sehingga peningkatan kinerja harus mendapat perhatian manajemen dan indikator kepatuhan terhadap standar kerja berkorelasi terendah terhadap disiplin kerja sehingga manajemen perlu meningkatkan perhatian dan kesadaran dalam meningkatkan kepatuhan terhadap standar kerja dalam memenuhi pekerjaan. kepuasan karyawan di Kecamatan Pajarakan Probolinggo.

\section{A B S T R A C T}

This research intends to know and analyzes the incentive and work discipline of its effect on employee job satisfaction in Pajarakan Sub-district, Probolinggo. The type of explanatory research is to find the influence or causal relationship between variables, The population of all employees in Pajarakan sub-district with the technique of purposive sampling using inclusion criteria is permanent employees and those who are willing to be respondents as much as 20 people, the analysis of multiple linear regression with $F$ test and t-test as a hypothesis test. The result of the study describes the incentive and work discipline has simultaneous influence on job satisfaction, and partially incentive variable has a significant and dominant influence on job satisfaction variable while work discipline variable partially have a positive but not significant influence on the variable of job satisfaction indicates the application of work discipline needs sufficient understanding and awareness. Performance indicators have the lowest correlation to incentives so that performance improvement should receive management attention and compliance indicator on the lowest correlate working standard to the work discipline so that management need to increase the attention and awareness in increasing the compliance to the standard work in fulfilling job satisfaction of employees in Pajarakan Sub-district Probolinggo. 



\section{Introduction}

The most important asset in a government agency is Human Resources, because of its role as the subject of policy implementers and operational activities. To obtain optimal performance results in human resources be managed as well as possible so that in a government agency can perform the duties and obligations to obtain optimal results. In general, the duties and obligations of the government are to create regulation of public services for the development of productive resources, to create peace and order of society, to preserve cultural social values and to strengthen the unity of the nation, to develop democratic life, to create justice, to conserve the environment, invite and develop the life of nation and state. To realize these tasks would require reliable human resources, having a good discipline reflects the magnitude of a person's sense of responsibility towards the tasks assigned to him. This encourages the passion and morale of employees and the realization of goals organization and community satisfaction. According to Hasibuan (2012: 193), Discipline is the awareness and willingness of a person to comply with all organizational rules and social norms that apply and have the adequate ability in order to achieve organizational goals.

The purpose of government agencies is to realize the welfare of the community through the enhancement of regional competitiveness, population-based economic growth, and optimization of sustainable resource management, and to realize a noble society through improving the quality of regional autonomy implementation in good governance and clean. To obtain reliable human resources supported by the provision of incentives that are part of compensation, according to Simamora in Kadarisman (2016: 182) the incentive here is a form of direct payment that based or directly linked to the performance gain sharing with performance intended as profit sharing for employees due to increased productivity or cost savings. Government agencies expect that given incentives earn greater performance benefits. Thus, the value of employee performance should be greater than the incentives paid by government agencies, so that government agencies get a good reward from other government agencies. With this incentive will provide employee job satisfaction.

According to Handoko (2014: 193) job satisfaction is a pleasant or unpleasant emotional state by which employees look at their work. To get the level of job satisfaction required a leader of government agencies are required to have a policy or program addressed to employees. In government agencies, it is also necessary that a leader can help create incentives that result in more satisfying work.Government agencies, in this case, are Pajarakan sub-districts use various incentives to attract and retain their employees in order to achieve the goals of agencies and personal. A leader can also help create incentives that produce more challenging and rewarding jobs. Because employees consider these incentives important, these incentives have a significant impact on employee performance and performance at the Pajarakan District Office Probolinggo District.

In the Office of government agencies in sub-district Pajarakan which has implemented good financial incentives with the aim to increase employee satisfaction. In the provision of financial incentives in the form of additional wages seen from absenteeism and work activities, this direct links between the incentive and discipline of employees who see from the level of attendance or absenteeism but in reality still found employees who come late and return home before the set home hours. So the problem causing a reduction of incentives to employee satisfaction in Pajarakan Sub-district, Probolinggo District. Discipline much upheld in this government institution because it directly related to the public services of various disciplines that enforced, among others: (1) the tolerance limit for the delay is ten minutes but will recorded as a bad condition. (2) If within one month of work permit does not go to work for any reason then it is not entitled to attendance bonus. (3) If within one month of work do half-day permit more than three times for any reason they do not get attendance bonus. (4) If within one month of work accumulated delays exceeding sixty minutes then no attendance bonus provided.

Therefore, to encourage employees to carry out government regulations with sincerity and responsibility, the leadership must provide decent incentives for employees. Which is a remuneration given by the government to employees who can be valued with money and have a tendency to give permanently In addition to other incentive issues; the incentives provided are not in accordance with the quality and work quantity. Employees get the same salary even if employees are better performers or do not do the job at all. These things cause employees to have no morale to improve their work discipline. Based on the above description, the authors are interested to conduct research entitled "the influence of giving incentives and the application of work discipline to the working satisfaction of permanent employees in the office of Pajarakan sub district, Probolinggo".

The formulation of the problem is: Is there a significant influence partially or simultaneously between incentives and work discipline on employee job satisfaction and which is dominant among the incentives and work discipline on employee job satisfaction? 
This research is done to employees in Pajarakan sub-district office because in this sub-district office is one of the sub-district government agencies that have rewarded incentives to their employees who have performed well. And sample 20 respondents from 37 population (all employees) in Pajarakan sub-district office with criteria only permanent employees who have employee identity number and who are willing to fill out questionnaires, select only permanent employees because permanent employees have full responsibility for their work. While the purpose of research to determine the influence of partial or simultaneous between incentive variables and work discipline variables on job satisfaction variables. And which is dominant among variable of incentive and work discipline variable to job satisfaction variable. Hypothesis in this research is incentive variable and work discipline variable partially and simultaneously have a significant influence, and incentive variables are more dominant compared to variable of work discipline to job satisfaction of employee at Pajarakan Sub-district office, Probolinggo

Incentive

Understanding Incentives, Incentives are compensation programs that link payments with products that need to elaborate to further promote higher work productivity, many organizations embrace incentive systems as part of the reward system that applies to employees of the organization, Simamora in Kadarisman (2016: 182). Furthermore, incentives are rewards or rewards given to motivate workers or members of the organization for high motivation and productivity, its nature is not fixed or at any time. Thus, it can argue that incentives are a variable element of income or remuneration provided on a fixed or variable basis depending on the conditions of achievement of employee performance. It intended that this type of income component attribute directly between the rewards earned by an employee and the accomplishments he has achieved, Yuniarsi and Suwatno in Kadarisman (2016: 191).

Incentives are growing as they increase the demand for competition in the business world, especially among government agencies or similar organizations. The incentive system shows the clearest relationship between compensation and work performance. In other words, the term incentives commonly used to describe payroll plans that directly related to the standards of employee productivity or organizational profitability or both. Different forms of incentive plan link wage to individual productivity, other plans with productivity or overall organizational profitability. Employees working under a financial incentive system mean that their work performance determines, incompletely or in part, their income.

Thus, the incentive here is a form of direct payment that based or directly linked to performance intended as a benefit-sharing for employees due to increased productivity or cost savings, this done as a strategy to increase productivity and efficiency by companies or organizations in the face of increasing competition tight in the business world. In this connection, productivity is very important by utilizing the behavior of employees who have a tendency to work potluck or not optimal in the system of receipt of the fixed amount of compensation and will work optimally if the performance is directly related to rewards called incentives.

Also when associated with reinforcement theory that employees will work maximally when a job brings a very important consequence for a worker, for money can be an important tool for fulfilling primary motives such as physical needs, security, and recognition.According to Nasution in Kadarisman (2016: 193) explains that this incentive compensation money is out of money or wages received by employees. Because the same employee salary is the same, but the rewards earned by employees each month can be different. The reason is the incentive compensation is what causes the differences received by the employee. Thus, the incentives here are as a strategy to increase productivity and efficiency by government agencies in the face of increasingly fierce competition in the business world.

Incentive Purposes; the fundamental goal of all incentive programs is to increase employee productivity in order to achieve a competitive advantage. Incentive programs pay an individual or group for what exactly they produce. Furthermore, the main purpose of incentives is to provide responsibility and encouragement to employees in order to improve the quality and quantity of their work. As for the company, the incentive is a strategy to increase the productivity and efficiency of government agencies in the face of increasingly fierce competition, namely, productivity becomes one very important thing, Zainal (2014: 560).

The ultimate goal of all incentive programs is to increase employee productivity in order to achieve a competitive advantage. Incentive programs pay individual or group employees for exactly what they produce. On the other hand, the main purpose of incentives is to give employees responsibility and encouragement in order to improve the quality and quantity of their work. As for the company, incentives are a strategy to increase the productivity and efficiency of government agencies in the face of increasingly fierce competition, namely, productivity becomes one very important thing, Kadarisman (2016: 205). 
According to Zainal (2014: 560) suggests incentive systems exist in almost every type of work from manual labor to professionals, managers and executive workers, the general incentives are as follows: Piecework, is an incentive given on the basis of the amount of output or goods produced by the worker. Production bonus is an additional wage received because the work exceeds the specified standard, the employee also gets the basic wage. Commission, an incentive given based on the number of items sold. Matur curve, incentives can be grouped in a range from minimal to max. Merit pay, acceptance of wage increases occurs after an appraisal of achievement. Pay for knowledge/pay for skill compensations, providing incentives based not on what the employee does will produce tangible products, but on what do to the organization through acquired knowledge, assumed to have a large and important level of influence for the organization. Non-monetary incentives, incentives are generally in the form of money, but incentives can also be in other forms, such as (certificates, holidays etc.). Incentive executive is a bonus given to managers or executives for the role they give to them to gain and achieve a certain level of profit for government agencies.

Incentive Indicators, Some basic calculation/consideration of incentive compilation based on indicators as follows: 1 . Performance, Incentive system in this way directly attributes the amount of incentive to the performance that has shown by the employee concerned. 2. Duration of Work, The amount of incentive is determined based on the length of the employee performing or completing a job. 3.Seniority, This incentive system based on the employment or seniority of the employees concerned in an organization. 4. Needs, this means that employee incentives based on the level of urgency of decent living needs of employees. 5. Justice and feasibility the incentive system should be related to the relationship between sacrifice (input) and (output), the higher the sacrifice the higher the expected incentives, and therefore be judged is the sacrifice required by a position. In addition to justice issues in the provision of incentives should also be noted the issue of feasibility. Worthy of understanding compare the number of incentives with other companies engaged in similar business. 6. Evaluation of position, Determination of relative value or price of a position to rank in incentive determination, Handoko in Dharmayanti journal (2015: 17).

Work Discipline.

Understanding, Some understanding of work discipline put forward by some experts, as follows: Singodimedjo (2009: 90) said discipline is the attitude of willingness and willingness of a person to comply and obey the norms of the regulations in force around him. Simamora (2006: 610) states that Discipline is a procedure that corrects or punishes subordinates for violating rules or procedures. Siswanto (2005: 291) Discipline is an attitude of respect, respect, obedience and obedience to the rules that apply, both written and unwritten and able to run it and not evasive to accept the sanctions if he violates the duties and authority given to her. Hasibuan (2012: 193) discipline is the awareness and willingness of a person to comply with all organizational rules and social norms that apply. Sinungan (2000: 146) describes the discipline of work as a mental attitude reflected in the actions or behavior of individuals, groups or communities in the form of obedience or obedience to regulations established by the government or ethics, norms, and rules applicable in the community for a particular purpose. Zainal (2014: 599) suggests a work discipline is a tool used by managers to communicate with employees so that they are willing to change a behavior and in an effort to increase one's awareness and willingness to comply with all organizational rules and prevailing social norms.

From the description above, it is seen that the discipline is basically a management action to motivate the members involved in the organization to meet various provisions, rules and work ethics applicable within an organization which includes the existence of the rules, procedures and provisions, on the run with obedience by his followers, as well as the existence of sanctions/penalties for the offender.

Forms of Work Discipline, According Zainal (2014: 599) is as follows: Retributive discipline, which is trying to punish the wrongdoer. Corrective Discipline, which seeks to help employees correct his inappropriate behavior. The perspective of Individual Rights, which seeks to protect the basic rights of individuals during disciplinary actions. The Utilitarian Perspective, focusing on the use of discipline only when the consequences of disciplinary action outweigh its negative effects.

Type of discipline, Self-imposed discipline is the most effective type of discipline, because employees have a work discipline that not caused by fear of sanctions or penalties received, if not obedient against the boss, but arises because of the employee's own awareness of his duties and responsibilities. Discipline by command (command discipline) is a discipline that arises because of coercion and driven by the fear of sanctions be imposed by superiors if the order is not obeyed, Sukarna (2001: 105).

Indicators of Work Discipline, According Siswanto in Sinambela (2016: 356) argues that the indicator of the discipline of work there are five. 1)The frequency of presence. One of the benchmarks to know the level of employee discipline is the higher the frequency of attendance or low levels of absentee 
then the employee has a high work discipline. 2) Level of vigilance. Employees who in carrying out their work is always full of calculations and accuracy has a high level of awareness to both himself and his work. 3) Adherence to work standards. In carrying out its work, an employee is required to comply with all work standards that have established in accordance with the rules or guidelines for work accidents do not happen or can avoid. 4) Compliance with work regulations. It intended for comfort and fluency in work. 5) Work ethics. Work ethics required by every employee in carrying out his work to create a harmonious atmosphere, mutual respect among fellow employees.

Purpose of Work Discipline; According Siswanto (2005: 292) the general purpose of the discipline of work is for the sake of the organization in accordance with the relevant organizational motifs, both today and tomorrow. The specific purpose of the discipline of work, among others, so that the workers keep all regulations, employment policies, regulations, and policy organizations that apply, both written and unwritten, and implement management orders. Can perform the best work and able to provide maximum service to certain parties with an interest in the organization in accordance with the field of work given to him. Can use and maintain facilities and infrastructure of goods and services of the organization as well as possible. Can act and behave in accordance with the norms that apply to the organization. The workforce is able to obtain a high level of productivity in line with organizational expectations, both in the short and long term.

Sanction of Work Discipline Violation; According to Zainal (2014: 450) there are several levels and types of work violations that generally apply in an organization namely: Sanctions for minor offenses, with types: oral warning, written warning, and dissatisfaction in writing. Medium offense sanctions, with types: postponement of salary increase, a decrease in salary, postponement of promotion. In addition, Sanctions of serious offenses, by type: demotion, exemption from office, dismissal, dismissal.

Job satisfaction

Understanding Job Satisfaction, According Sutrisno (2012: 74) Job satisfaction is a sense that sees job satisfaction as a complex emotional reaction. Moreover, an employee's attitude towards work related to work situations, inter-employee cooperation, rewards received in the work, and matters of physical and psychological factors. Employees who do not get job satisfaction will never achieve psychological satisfaction and will eventually arise a negative attitude or behavior and in turn will lead to frustration, otherwise satisfied employees will be able to work well, energetically, actively and can perform better than employees who do not get job satisfaction. Job satisfaction is one of the factors that can affect the satisfaction of life because humans most of the time spent in the workplace.

Many theories that discuss job satisfaction in various literature as follows:

Value Theory (Value theory), this concept occurs at the level when the result of the work received by the individual as expected. The more people receive the results, the more satisfied and vice versa. Focus on any outcome that judges people regardless of who they are. This value theory focuses on any outcome that judges people regardless of who they are. The key to job satisfaction in this approach is the difference between the aspects of work one has and one wants. In this case, the greater the difference, the lower the satisfaction of the person. The implications of this theory on aspects of work that need to change to gain job satisfaction.

This theory emphasizes that job satisfaction can be derived from many factors, i.e. by effective means of satisfying workers by finding what they want and when possible giving it. The weakness of this theory is the fact that people's satisfaction also determined by individual differences. Moreover, it is not a linear relationship between the magnitude of compensation and the level of satisfaction is more contrary to reality.

The Equilibrium Theory (Equity Theory), this theory suggests that in the organization there must be a balance. The components of this theory are input, outcome, comparison person, equity in equity. According to Wexley and Yukl in Sinambela (2016: 305) suggests that: a) Inputs are all values received by employees who can support the executive. b) The outcome is all values obtained and felt by employees. c) Comparison Person is an employee of the same organization, an employee in a different organization or himself in a previous job.

According to this theory, the satisfaction of employees is a result of the comparison they make between their inputs with the comparison of other employee outcomes. Therefore, if the comparison felt balanced then the employee was satisfied. Conversely, if not balanced then it can cause dissatisfaction.

Discrepancy Theory, This theory measures the satisfaction can do by calculating the difference between what should be with the reality felt by the employee. Locke in Sinambela (2016: 305) argues that employee job satisfaction depends on the difference between what expected by the employee. If what employees get is bigger than what is expected then they will be satisfied. Conversely, if the obtained employee is lower than expected then will cause dissatisfaction. 
Need Fulfillment Theory, According to this theory, employee job satisfaction depends on whether or not the employee needs fulfillment?Employees will be satisfied if they get what they need. The greater the needs of employees fulfilled the more satisfied they tooprevious work.

The Social Reference Group Theory, according to this theory, employee job satisfaction is not dependent on the fulfillment of needs alone, but also depends on the opinions of the group by which the employees used as a benchmark to assess themselves and their environment. Therefore, an employee feels satisfied if the work is in accordance with the interests and needs expected by the referral group.

The Two-Factor Theory According to this theory, employee job satisfaction is not dependent on the fulfillment of needs alone, but also depends on the perceptions of the working group on job satisfaction and job dissatisfaction through a separate dimension as expressed by Herzberg in Sinambela (2016: 306). Therefore, employees in their work can enter into various combinations of positive results that will overshadow high job satisfaction or low dissatisfaction. A person's job satisfaction is reciprocal with life's satisfaction. Life satisfaction derived from work factors as well as from non-working factors. Both of these satisfactions will contribute to the satisfaction of life, which will affect physical health, spiritual health, and others.

Factors that affect job satisfaction, namely: Psychological factors; is a factor associated with psychiatric employees, which includes interest, peace in work, attitudes toward work, talents, and skills. Social factors; is a factor associated with the social interaction between employers and employees over. Physical factors; is a factor associated with the physical condition of the employee, covering the type of work, setting time and rest time, work equipment, the state of the room, temperature, lighting, air exchange, employee health conditions, age and so forth. Financial factors are factors related to employee guarantees and welfare, which includes the system and the amount of salary, social security, various benefits, and facilities provided, promotion and so on.

Indicators Employee Satisfaction, According to Smith in the journal Arifin (2012-14) states there are 5 (Five) dimensions that affect the effective response of a person to his work, namely : 1) Work That Yourself, The extent to which the job provides an opportunity for a person to learn to take responsibility in a task and challenge for an interesting job. 2) Paid, Wages earned by someone is proportional to the effort made and equal to wages received by others in the same working position. 3) Colleagues, The extent to which co-workers are technically proficient and socially supportive of other co-workers. 4) Opportunity for Promotion, Opportunity for a person to achieve or promoted to a higher level within the organization or company. 5) Bosses, Ability superiors to provide technical assistance and support to the work that the subordinates are responsible.

Research Framework.

In this research, the researcher intends to know the variable of incentive in measured by indicator: (performance, duration of work, seniority, needs, fairness and eligibility and job evaluation). and variable of work discipline which measured by indicator: (frequency of attendance, level of awareness, adherence to work standards, compliance to work rules, and work ethics) influence on employee job satisfaction as measured by indicators: (job itself, paid, coworkers, opportunity for promotion, and superiors) in Pajarakan sub-district of Probolinggo regency thus as independent variable is incentive variable (X1) and work discipline variable (X2) and as dependent variable of employee job satisfaction (Y).

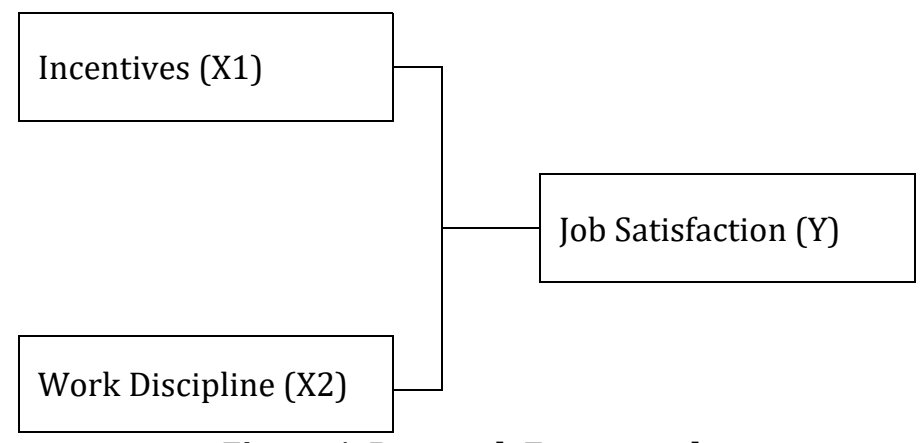

Figure 1. Research Framework

Source: data processed, 2017 


\section{Methods}

Types of research; the research used is explanatory that is a research that explains the causal relationship between research variables and hypothesis testing. Therefore, this research also often called hypothesis-testing research, namely research that analyzes the relationship between variables that formulated. If for the same data the researcher explains the causal relationship between the variables through hypothesis testing, then the research no longer called descriptive research but the research testing or explanatory research, Singarimbun (2011: 5).

Population and sample; Population is a whole set of elements that can be used to make conclusions, Hermawan (2016: 122). The population is a generalization area consisting of objects or subjects that have certain qualities and characteristics set by the researcher to be studied and then drawn a conclusion, Sugiyono (2017: 80).In this study, the population used all employees in the Pajarakan sub-district Probolinggo. Sampling technique is purposive sampling with inclusion criteria only permanent employees who are willing to fill out questionnaires presented by researchers as much as 20 respondents. Research instrument with questionnaire and Measurement Scale using Likert scale is measurement scale, which is agreement, which used as a reference to determine short length interval existing in measuring instrument so that measuring instrument when used in measurement will yield quantitative data. In this research, the Likert scale is used, the measurement scale used to measure the attitude, opinion, and perception of a person or group of people about a social phenomenon, Riduwan (2008: 20).

Data analysis, Multiple linear regression analysis, Regression is a method or method of fitting of an empirical fact which in geometric mathematical concept is depicted in scatter graph and the result of good fitting gives the smallest deviation result, it needs statistical understanding such as coefficient of determination and correlation, Hermawan (2016: 164). Multiple linear regression analysis is done if it has fulfilled the validity and reliability test and the classical assumption test, with hypothesis assessment using $\mathrm{F}$ test and $\mathrm{t}$-test.

\section{Result and Discussions}

Data Description, This study examines the incentives, discipline of work influence on employee job satisfaction, with purposive sampling technique with inclusion criteria i.e. permanent employees, and want to be respondents, where the respondents in this study are employees of Pajarakan District Office Probolinggo, amounting to 20 people. In addition to the identities of the number of respondents examined can describe in general by sex and education level that can describe as follows:

Table 1. Sex of Respondents

\begin{tabular}{llll}
\hline No & Gender & Number of Respondents & Percentage \\
\hline 1 & Male & 16 & $80 \%$ \\
2 & Woman & 4 & $20 \%$ \\
\hline Total & 20 & $100 \%$ \\
\hline
\end{tabular}

Source: data processed, 2017

From the data, the table above shows those male respondents as many as 16 employees with $80 \%$ percentage and women as many as four employees with a percentage of $20 \%$. So male respondents' more than female respondents.

Table 2. Respondents Education Level

\begin{tabular}{llcl}
\hline No & Pendidikan & Number of Respondents & Percentage \\
\hline 1 & Elementary school & 0 & 0 \\
2 & Junior high schools & 0 & 0 \\
3 & High school & 5 & $25 \%$ \\
4 & Diploma & 0 & 0 \\
5 & Bachelor Degree & 14 & $70 \%$ \\
6 & Masters & 0 & 0 \\
7 & Doctoral & 1 & $5 \%$ \\
\hline \multicolumn{2}{l}{ Total } & 20 & $100 \%$ \\
\hline
\end{tabular}

Source: data processed, 2017 
From the table above shows that respondents with high school background of 5 people with a percentage of $25 \%$, Bachelor education as many as 14 people with a percentage of $70 \%$ and doctoral education as much as 1 person with a percentage of $5 \%$. So the respondents are more educated Bachelor Degree with 14 employees.

Validity Test, Validity is data that has collected accurately derived from the questionnaire. According to Arikunto (2010: 168), Validity is a measure that indicates the validity of an instrument. To test the validity of this research used Product Moment correlation formula (Pearson correlation test). The validity test intended to correlate each item in a variable value with a total score of variables to get the validity index. If the probability of the correlation result is less than 0.05 then it is valid and vice versa if the probability of the correlation result is greater than 0.05 then it declared invalid. From the result of validity test all indicator variable show value of Sig count smaller than 0,05 . Means the instrument in this study can measure what will measure (valid).

Table 3. Validity Test or Correlation

\begin{tabular}{|c|c|c|c|c|}
\hline Variable & Indicator & $\mathrm{r}$ & Sig. & Information \\
\hline \multirow{6}{*}{ Incentive $\left(\mathrm{X}_{1}\right)$} & Performance & 0,862 & 0,000 & Valid \\
\hline & Duration of work & 0,915 & 0,000 & Valid \\
\hline & Seniority & 0,892 & 0,000 & Valid \\
\hline & Needs & 0,949 & 0,000 & Valid \\
\hline & Justice and feasibility & 0,913 & 0,000 & Valid \\
\hline & Evaluation of position & 0,900 & 0,000 & Valid \\
\hline \multirow{5}{*}{$\begin{array}{l}\text { Work } \\
\text { Discipline }\left(X_{2}\right)\end{array}$} & Frequency of presence & 0,916 & 0,000 & Valid \\
\hline & Level of vigilance. & 0,950 & 0,000 & Valid \\
\hline & Adherence to work standards & 0,810 & 0,000 & Valid \\
\hline & Compliance with work regulations & 0,878 & 0,000 & Valid \\
\hline & Work ethics & 0,862 & 0,000 & Valid \\
\hline \multirow{5}{*}{$\begin{array}{l}\text { Job } \\
\text { Satisfaction(Y) }\end{array}$} & Work That Yourself & 0,922 & 0,000 & Valid \\
\hline & Paid & 0,911 & 0,000 & Valid \\
\hline & Colleagues & 0,919 & 0,000 & Valid \\
\hline & Opportunity for Promotion & 0,930 & 0,000 & Valid \\
\hline & Bosses & 0,964 & 0,000 & Valid \\
\hline
\end{tabular}

Source: data processed, 2017

Reliability Test, According to Arikunto (2010: 170) Reliability shows in a sense that a fairly reliable instrument to be used as a means of data collection because the instrument is good, Riduwan (2008: 220) Explained that reliability testing is done to obtain the accuracy of the instrument collection tool used, the instrument can be said reliably if it has a reliability coefficient of $\geq 0.60$. Reliability test results showed 0.978 greater than 0.60 so it can be concluded the instrument in this study is good.

Table 4. Reliability Test

\begin{tabular}{lllll}
\hline No & Cronbach's Alpha & Alpha Comparator & N of Items & Information \\
\hline 1 & 0,978 & 0,6 & 16 & Valid \\
\hline
\end{tabular}

Source: data processed, 2017

Multiple Linear Regression Analysis. Prior to the analysis of regression instruments and data have been tested the validity, reliability and test of classical assumptions with results that qualify for the multiple linear regression analysis, from the regression analysis resulted in the incentive variable regression coefficient (X1) of 0.565 which means that every increase one unit of incentive variable will increase the contribution of employee job satisfaction by $56.5 \%$. And regression coefficient of the variable of work discipline (X2) equal to 0,330 which means that every increase of one unit of work discipline variable will increase the contribution of job satisfaction of employee equal to $33,0 \%$. From the results of multiple 
linear regression, analysis can written the following regression equation below: $\mathrm{Y}=-0.337+0.565 \mathrm{X} 1+$ $0.330 \times 2$.

Table 5. Multiple Linear Regression Coefficients

\begin{tabular}{llllll}
\hline Variable & $\begin{array}{c}\text { Regression } \\
\text { Coefficient }\end{array}$ & t-count & t-table & Sig. & Information \\
\hline Constant & $-0,337$ & $-0,185$ & & 0,855 & \\
Incentive $\left(\mathrm{X}_{1}\right)$ & 0,565 & 3,178 & 2,10092 & 0,006 & Significant \\
Work Discipline $\left(\mathrm{X}_{2}\right)$ & 0,330 & 1,574 & 2,10092 & 0,134 & Not significant \\
\hline
\end{tabular}

Source: data processed, 2017

F-Test. In order to test the hypothesis simultaneously the influence of incentive variables and work discipline variables on employee job satisfaction in Pajarakan Sub-district Probolinggo District. The result of $\mathrm{F}$ test shows that the $\mathrm{R}$ square value of 0.895 which means the incentive variable and the work discipline variable as the independent variable have simultaneous effect of $89.5 \%$ on the dependent variable of employee job satisfaction and the remaining $10.5 \%$ in influencing other variables outside this research. And F-count 72,251 bigger than F-table 3,5915 thus incentive variable and work discipline variable have the significant simultaneous influence on employee satisfaction variable, thus his hypothesis is received.

Table 6. F-Test

\begin{tabular}{lllll}
\hline R Square & F-count & F-table & Sig. & Information \\
\hline 0,895 & 72,251 & 3,5915 & 0,000 & Significant \\
\hline
\end{tabular}

Source: data processed, 2017

T-Test,see Table 5. In intended to test the hypothesis partially influence the variable incentives and work discipline variables on employee job satisfaction in Pajarakan Sub-district Probolinggo. The result of t-test show incentive variable have t-count equal to 3,178 bigger than $t$-table equal to 2,1092 thus incentive variable have the partially significant positive effect on employee satisfaction variable, hence its hypothesis accepted. In addition, the work discipline variables have t-count of 1.574 smaller than $t$-table of 2.1092 thus variable work discipline has a positive but not significant effect on employee job satisfaction variable, then the hypothesis is rejected. From t-test can be in the know that incentive variable dominant than the variable of work discipline, hence its hypothesis received.

Discussion

Incentives influence on Employee Satisfaction, from the results of research variables that are measured incentives with indicators; (performance, duration of work, seniority, needs, fairness and eligibility and job evaluation) on job satisfaction shows positive and significant results which means that with the incentive will increase employee job satisfaction in Sub district Pajarakan Probolinggo, this is in line with the main objectives of every organization to design incentive system is to motivate employees in improving their performance and retain competent employees, Zainal (2014: 560). By designing a good incentive system will have a double impact on the organization or the Company, because on the one hand the incentive will affect the efficiency of the organization and increase employee motivation, on the other hand, the incentive will affect the behavior and work attitude that leads to the feeling of job satisfaction in accordance with the desire organization for employees to improve their performance. This is understandable because one of the goals of a worker expects reward and a feeling of satisfaction from the organization in which he works, while the organization expects employees to provide the best performance for the organization. This is in line with the theory of Need Fulfillment according to this theory; employee job satisfaction depends on whether or not the employee needs satisfaction, Sinambela (2016: 306). Employees will be satisfied if they get what they need. The greater the needs of employees are fulfilled the more satisfied they too.

Work Discipline influence on Employee Satisfaction, from the results of research indicates work discipline in measured by indicators; (frequency of attendance, level of awareness, adherence to work standards, adherence to work rules, and work ethics) have a positive but insignificant effect on job satisfaction This employee illustrates that the application of discipline is basically good but if not communicated properly will have an impact on behavior unfavorable to employees one of them is dissatisfaction, this is in line with Zainal, (2014: 599) argues that: Work discipline is a tool used by managers to communicate with employees so that they are willing to change a behavior as well as in an 
effort to increase awareness and willingness one obeys all organizational rules and prevailing social norms. From the results of the study of discipline to give a positive but insignificant effect on the work satisfaction of this employee illustrates that the application of discipline, of course, required a good understanding and awareness for the employees and if the understanding and consciousness are not fulfilled of course that appears is disappointment and dissatisfaction, review Hasibuan opinion (2012: 193) Discipline is the awareness and willingness of a person to comply with all organizational rules and prevailing social norms. And the opinion Singodimedjo (2009: 90) said the discipline is the attitude of willingness and willingness of a person to comply and obey the norms of regulations in force around him.

Human beings are the dominant and most important resource in the organization or the Company. Thus if they want a good performance then the man must have a good discipline attitude because it very impacts on performance with good performance will contribute to the sustainability of the organization which in turn the organization will provide compensation to employees it will certainly increase job satisfaction and employee motivation. So the discipline of good employee work will give satisfaction to the employees themselves because with the discipline will have a positive impact on the organization and employee performance that automatically the organization will give attention to all members. In general, good discipline when employees come to the office or workplace regularly and on time, ethics good work, dressed well in the workplace. Use materials and equipment with care and work always follow/obey the rules or work procedures that have agreed.

The role of discipline is not less important with other principles means that discipline every employee always affect the results of work performance. Therefore, in every organization should be emphasized discipline employees-employees. Through high discipline, the productivity of employees can improve in essence. Therefore, it needs to be implanted to every employee of discipline as well as possible. Sinabung (2000: 146) describes the discipline of work as a mental attitude that reflected in the actions or behavior of individuals, groups or communities in the form of obedience or obedience to regulations set by either government or ethics, norms, and rules that apply in society for a particular purpose. Furthermore, everything that will be meaningless if not disciplined by the executor. The above description can conclude that the higher the level of discipline an employee will be the higher the performance of employees who have a positive impact on the continuity of the organization and consequently satisfaction and welfare of employees will meet.

\section{Conclusion and Reccomendations}

Variable incentives measured by indicators; (performance, duration of work, seniority, needs, fairness and eligibility and job evaluation) give a partial and significant influence on employee job satisfaction as measured by the indicator; (the job itself, the pay, the coworkers, the opportunity for promotion, and the boss). Indicator needs that have given the greatest correlation to incentive variables while performance indicators provide the lowest correlation to incentive variables but overall existing indicators have contributed to employee job satisfaction in Pajarakan Sub-district Probolinggo District.Variable work discipline as measured by indicator; (frequency of attendance, level of awareness, adherence to work standard, obedience to work regulation, and work ethic) also give positive partial influence but not significant to employee satisfaction variable that measured by indicator; (the job itself, the pay, the coworkers, the opportunity for promotion, and the boss). The alertness indicator has given the greatest correlation to the variables of work discipline while the indicator of compliance with the working standard provides the lowest correlation. Thus, the discipline of work gives a positive but not significant impact on job satisfaction. While the variable of job satisfaction of employee is measured by the indicator; (the job itself, the pay, the coworkers, the opportunity for promotion, and the boss). The superior indicator has given the most correlation while the pay indicator gives the lowest correlation.

Variables of incentive and work discipline have been proved to have a significant simultaneous effect on employee job satisfaction in Sub district Pajarakan Probolinggo and the influence of simultaneously equal to $81,6 \%$ to job satisfaction of employee and the remaining $18,4 \%$ in the influence of others variable outside this research.

Variable incentives measured by indicators; (performance, duration of work, seniority, needs, fairness and eligibility and job evaluation) performance indicators become weak points because of their low correlation makes the attention to management to perceive performance as a priority and attention in providing incentives and performance improvements in the future so that employee job satisfaction more increased. While the variables of work discipline with the indicator of compliance on the work standards that need to be improved because it has given the lowest correlation, management with increased attention to the compliance to the work standards expected work patterns and employee behavior will change and the performance of employees in the Pajarakan Sub District Probolinggo will increase so that achievement and the continuity of the organization will progress and both the impact will give a sense of job satisfaction to employees. 
Frankly, with the differences in time, place, environmental conditions, variables or factors that affect employee job satisfaction are still many outside of the two variables incentive and work discipline variables in this study for it encourages for further research related to employee job satisfaction.

Thanks to the Pajarakan district leaders and staff who have provided the opportunity to conduct research in this place, thanks also to my students "Rani Andreani" for helping us with the research and thanks to my leader who has given me the assignment letter and permission to conduct research as well as all parties who help and cannot be mentioned here.

\section{References}

Arifin, Noor. 2012. Quality Analysis of Work Life, Performance, and Job Satisfaction at CV. Ambassador Senenan Jepara. Faculty of Economics, State University of Yogyakarta Vol 8, No. 1

Arikunto, Suharsimi. 2010. something Procedures Approach Practice Approach. Fourteenth Print. Jakarta: PT. Rineka Cipta

Dharmayanti, Diana. 2015. Basic Influence Determination of Financial Incentives and Work Motivation in Employee Performance Sales Section PT Sumber Ceria Bersama Surabaya Branch. Business Management Program, Management Studies Program, Petra Christian University Vol 3, No 1

Handoko, Hani. 2014. Personnel and Human Resource Management. Matter of the Twenty-One. Yogyakarta: BPFE

Hasibuan, Malayu S.P. 2012. Human Resource Management. Revised Edition, Sixteenth Edition. Jakarta: PT. Earth Script.

Hermawan, Sigit. \& Amirullah. 2016. Business Research Methods Quantitative and Qualitative Approach. Malang: Nusa Creative Media.

Kadarisman. 2016. Compensation Management. Print three. Jakarta: Rajawali Pers.

Riduwan. \& Engkos Achmad Kuncoro. 2008. How to Use and Mean Path Analysis (Path Analysis). Bandung: Alfabeta.

Simamora, Henry. 2006. Human Resource Management. Revised Edition III. Jakarta: Gramedia Pustaka Utama

Sinambela. 2016. Human Resource Management. First Print. Jakarta: PT Bumi Aksara

Singarimbun, Masri. 2011. Research Methods Survey. Jakarta: LP3ES.

Singodimedjo, Markum. 2009. Human Resource Management. Surabaya: SMMAS.

Sinungan, Muchdarsyah. 2000. Productivity: What and How. East Jakarta: Earth Script.

Siswanto, Bejo. 2005. Indonesian Manpower Management Administrative and Operational Approach. Jakarta: Earth Literacy.

Sugiyono. 2017. Quantitative Research Methods, Qualitative, and R \& D. Bandung: Alfabeta.

Sukarna. 2001. Human Resource Management Organization. Surabaya: UIN Sunan Ampel.

Sutrisno, Edy. 2012. Human Resource Management. Fourth Print. Jakarta: Prenada Media Group.

Zainal, Veithzal Rivai. ET. 2014. Human Resource Management for Companies from Theory to Practice. Third Edition Depok: Rajagrafindo Persada. 